\title{
ANALISIS DRUG RELATED PROBLEMS (DRPS) PADA PASIEN RAWAT JALAN DIABETES MELITUS TIPE 2 DI UPT PUSKESMAS RAWAT INAP GEDONG AIR BANDAR LAMPUNG
}

\section{ANALYSIS OF DRUG RELATED PROBLEMS (DRPS) IN PATIENTS WITH PATIENTS DIABETES MELLITUS TYPE 2 IN PATIENT UPT PUSKESMAS RAWAT INAP GEDONG AIR BANDAR LAMPUNG}

\author{
Akhmad Rokiban ${ }^{1}$ Dwiauliaramdini ${ }^{1}$, , Sitijuwariyah ${ }^{2}$ \\ Fakultas MIPA, Jurusan Farmasi Universitas Tulang Bawang Lampung \\ Email : rokiban81@utb.ac.id \\ HP. 0821-7654-7781
}

\begin{abstract}
Abtract
Diabetes mellitus (DM) is a serious chronic disease that occurs because the pancreas does not produce enough insulin or when insulin is not use effectively in the body. This study aims to analyze the incidence of Drug Related Problems (DRPs) and find out the category of DRPs in outpatients with a diagnosis of type 2 diabetes mellitus at UPT Puskesmas Gedong Air Inpatient for the Bandar Lampung. This research is a nonexperimental research with a descriptive design taken retrospectively. The sampling technique used in this study is total sampling based on the patient's medical record data. Data were analyzed using the classification of DRPs according to Cipolle 2004, then using Medscape Tools as a tool to check potential drug interactions. The results of this study were 61 patients including 29 patients (46\%) with DRPs and 33 patients (54\%) without DRPs. The number of male patients is 25 patients and the number of female patients is 36 patients with age range 25-45 and 46-65. A total 52 patien Type 2 Diabetes Mellitus have cormobid and 9 patients without comorbid. DRP categories that occur include drugs without indication as much (8\%), indications without drugs as much as (15\%), and potential drug interactions (48\%). The conclusion in this study is that Drug Related Problems (DRPs) have occurred in outpatients diagnosed with type 2 diabetes mellitus in UPT Puskesmas Gedong Air Inpatient with the highest DRPs category is the potential for drug interactions (48\%).
\end{abstract}

Key words: Diabetes Mellitus Type 2, Drug Related Problems

\section{Abstrak}

Diabetes melitus (DM) adalah penyakit kronis serius yang terjadi karena pankreas tidak cukup menghasilkan insulin atau ketika insulin tidak digunakan secara efektif di dalam tubuh. Penelitian ini bertujuan untuk menganalisa kejadian Drug Related Problems (DRPs) dan mengetahui kategori kejadian DRPs pada pasien rawat jalan dengan diagnosa diabetes melitus tipe 2 di UPT Puskesmas Rawat Inap Gedong Air Bandang Lampung Penelitian ini merupakan penelitian noneksperimental dengan rancangan deskriptif yang diambil secara retrospektif. Teknik pengambilan sampel yang digunakan pada studi ini adalah menggunakan total sampling dengan berdasarkan data data rekam medik pasien. Data dianalisis menggunakan klasifikasi DRPs menurut Cipolle 2004, selanjutnya menggunakan Tools Medscape sebagai tools untuk mengecek potensi interaksi obat. Hasil penelitian diperoleh sebanyak 61 pasien diantaranya teridentifikasi terdapat DRPs sebanyak 29 pasien $(46 \%)$ dan tidak 
mengalami DRPs sebanyak 33 pasien (54\%). Jumlah pasien laki-laki 25 pasien dan jumlah pasien perempuan 36 pasien dengan rentang usia 25-45 dan 46-65. Pengakit penyerta Diabetes Melitus Tipe 2 sebanyak 52 pasien dan tidak penyerta sebanyak 9 pasien. Kategori DRPs yang terjadi antara lain obat tanpa indikasi sebanyak (8\%), indikasi tanpa obat sebanyak (15\%), dan potensi interaksi obat sebanyak (48\%). Kesimpulan dalam penelitian ini yaitu telah terjadi Drug Related Problems (DRPs) pada pasien rawat jalan dengan terdiagnosa diabetes melitus tipe 2 di UPT Puskesmas Rawat Inap Gedong Air dengan kategori DRPs paling tinggi adalah potensi interaksi obat sebanyak (48\%).

Kata kunci: Diabetes Melitus Tipe 2, Drug Related Problems (DRPs)

\section{PENDAHULUAN}

Diabetes melitus (DM) merupakan salah satu penyakit tidak menular (PTM) yang ditandai dengan tingginya kadar glukosa dalam darah (hiperglikemia). Jumlah kasus dan prevalensi diabetes terus meningkat selama beberapa dekade terakhir.Word Health Organization (WHO) memperkirakan secara global pada tahun 2014, penderita diabetes melitus sebesar 422 juta orang dewasa dengan usia diatas 18 tahun. Diperkirakan setengah dari kasus diabetes melitus di dunia berada di Asia Tenggara dan Pasifik Barat (1)

Berdasarkan Riset Kesehatan Dasar (RISKESDAS) tahun 2018 prevalensi penyakit $\mathrm{DM}$, pada usia $\geq 15$ tahun di Indonesia mengalami peningkatan dari $1,5 \%$ di tahun 2013 menjadi 2,0\% ditahun 2018. Provinsi DKI Jakarta menduduki urutan pertama dengan jumlah penderita terbanyak dan urutan kedua berada di Provinsi Bengkulu. Provinsi Lampung menduduki urutan ke 27 dari 34 Provinsi di indonesia (2). Menurut Profil Dinas Kesehatan Provinsi Lampung tahun 2015 mencatat data 10 terbesar seluruh penyakit, diabetes melitus menduduki peringkat ke 8 di Lampung (3).

Penyakit DM diklasifikasikan menjadi DM tipe 1, DM tipe 2, DM gestasional dan DM tipe lain-lain. DM tipe 2 merupakan jenis DM yang paling banyak diderita dibanding tipe yang lain (4). DM tipe 2 saling berkaitan dengan resistensi insulin disertai defisiensi insulin relatif, sampai yang defek sekresi insulin disertai resistensi insulin (5). Beberapa komplikasi seperti mikrovaskular, makrovaskular dan neuropati dapat muncul akibat penyakit DM (3). Pasien DM dengan komplikasi, biasanya akan mendapatkan terapi polifarmasi. Polifarmasi adalah meresepkan obat melebihi obat yang diperlukan secara klinis atau penggunaan obat lebih dari lima jenis obat (6). Polifarmasi salah satu faktor penyebab terjadinya Drug Related Problems (DRPs) (7). Drug related problems (DRPs) adalah kejadian yang tidak diinginkan oleh pasien yang mendapatkan terapi obat dan yang mengganggu pencapaian tujuan terapi yang diinginkan (8) .Kategori DRPs yaitu: obat tanpa indikasi, indikasi tanpa obat, obat yang tidak efektif, dosis terlalu rendah, efek samping obat dosis terlalu tinggi dan ketidak patuhan (8).

Studi identikasi DRPs pada pasien DM oleh Ayele et al melaporkan bahwa terdapat 364 kasus DRPs dengan kategori, terapi obat menjadi tidak optimal $49 \%$, indikasi tidak diobati $21,1 \%$, reaksi obat merugikan $19 \%$ dan pengobatan tanpa indikasi $10,7 \%$ (9). Studi identifikasi DRPs pada pasien DM tipe 2 oleh Nurwijayanti menyatakan bahwa kategori interaksi 
obat sebanyak 39 pasien $(81,25 \%)$

dengan 117 kasus (10). Studi identifikasi (DRPs) penggunaan obat antidiabetes pada pasien DM tipe 2 oleh Claudia Pinkan Lira et al didapatkan hasil kategori yang sering yaitu interaksi obat sebanyak $60 \%$, obat terkontraindikasi $4,44 \%$ dan kategori terapi obat tidak efektif yakni sebanyak $\quad 35,55 \% \quad$ (11). Studi identifikasi DRPs pada pasien DM tipe 2 disertai dislipidemia oleh Hasniza Zaman Huri et al terdapat bahwa DRPs kategori interaksi obat $(18,9 \%)$, kondisi yang tidak diobati $(10,8 \%)$ dan ketidakpatuhan $(10,8 \%)(12)$.

Dampak DRPs yang terjadi yaitu tidak mencapai hasil terapi yang diinginkan, menyebabkan bertambahnya masalah masalah baru pada pasien, seperti pemilihan obat tidak tepat menimbulkan interaksi obat, efek samping semakin banyak, dosis terlalu tinggi menyebabkan over dosis, pemberian dosis terlalu rendah menyebabkan tidak tercapainya hasil terapi yang diingikan (8).

Pelayanan kefarmasian di Puskesmas di lakukan berdasarkan konsep pharmaceutical care pelayanan yang berorientasi kepada pasien sesuai dengan pedoman masyarakat. Kegiatan farmasi klinik merupakan implementasi dari Pharmaceutical care. Salah satu kegiatan farmasi klinik adalah mengidentifikasi DRPs. Kegiatan ini penting dilakukan untuk meningkatkan efektivitas terapi dan kualitas hidup pasien (13).

Berdasarkan latar belakang tersebut perlu dilakukan penelitian mengenai Analisis Drug Related Problems (DRPs) pada pasien rawat jalan diabetes melitus tipe 2 di UPT Puskesmas Rawat Inap Gedong Air Bandar Lampung.

\section{METODE PENELITIAN}

Penelitian ini dilakukan di UPT Puskesmas rawat inap Gedong Air pada bulan November 2019. Jenis penelitian adalah non eksperimental dengan pendekatan deskriptif yang diambil secara retrospektif. Menggunakan rancangan penelitian Total Sampling yang bertujuan untuk mengetahui ada tidak kejadian Drug Related Problems (DRPs) pada pasien rawat jalan diabetes melitus tipe 2 di UPT Puskesmas rawat inap Gedong Air Bandar Lampung periode Agustus 2018-Agustus 2019. Kemudian dianalisis dengan menggunakan referensi standar Pharmaceutical Care Practice cipolle 2004, American Diabetes Assosiation (ADA) 2018, Basic Pharmacology and Drug Notes, Medscape.

\section{HASIL DAN PEMBAHASAN}

Penelitian ini menggunakan data dari rekam medik pasien rawat jalan penderita diabetes melitus tipe 2 dengan atau tanpa komplikasi yang berobat pada periode Agustus 2018Agustus 2019 di UPT Puskesmas Rawat Inap Gedong Air. Jumlah populasi ini sebanyak 66 pasien dari data rekam medik, dengan 61 kasus yang masuk kriteria inklusi dan dan 5 sampel yang masuk kriteria eksklusi karena pasien meninggal.

\section{Jenis Kelamin}

Berdasarkan hasil penelitian karakteristik jenis kelamin pasien yang paling banyak mengalami kasus DM tipe 2 yaitu pasien perempuan sebanyak 36 (59\%) dibanding dengan pasien laki-laki sebanyak 25 (41\%). Jumlah wanita yang menderita DM tipe 2 lebih banyak dibanding laki-laki juga dapat disebabkan karena tingkat sensitifitas terhadap kerja insulin pada otot dan hati. Estrogen adalah hormon yang dimiliki oleh wanita, peningkatan 
dan penurunan kadar estrogen dapat mempengaruhi kadar glukosa darah. Pada saat kadar hormon strogen mengalami peningkatan maka tubuh menjadi resisten terhadap insulin (14). Rincian berdasarkan jenis kelamin dapat dilihat pada tabel 1.

Tabel 1. Karakteristik Berdasarkan Jenis Kelamin

\begin{tabular}{clcc}
\hline No & Jenis kelamin & $\begin{array}{c}\text { Jumlah } \\
\text { Pasien }\end{array}$ & Persentase \\
\hline 1 & Laki-laki & 25 & $41 \%$ \\
2 & Perempuan & 36 & $59 \%$ \\
& Total & 61 & $100 \%$ \\
\hline & & & akan mengalami penyusutan sel-sel
\end{tabular}

Kelompok usia 25 tahun tidak ada pasien yang terdiagnosis DM tipe 2, usia 26-35 tahun tidak ada pasien yang terdiagnosis DM tipe 2, usia 36-45 tahun sebanyak 5 pasien (8\%), usia 4655 tahun sebanyak 17 pasien (28\%) dan usia 56-65 tahun sebanyak 39 pasien (64\%). Orang yang mempunyai usia lebih dari 45 tahun dengan pengaturan diet glukosa yang rendah beta pankreas. Sel $\beta$ pankreas yang tersisa pada umumnya masih aktif, tetapi sekresi insulinnya semakin berkurang. Kurangnya aktvitas fisik dan kekebalan tubuh menurun juga dapat menyebabkan seseorang rentan terhadap berat badan berlebih bahkan obesitas (15). Rincian berdasarkan usia dapat dilihat pada tabel 2 .

Tabel 2. Karakteristik Berdasarkan Usia Menurut Depkes 2009

\begin{tabular}{ccccc}
\hline No & Umur & Kategori Usia & Jumlah & Persentase \\
\hline 1 & 25 & Remaja akhir & 0 & 0 \\
2 & $26-35$ & Dewasa awal & 0 & $0 \%$ \\
3 & $36-45$ & Dewasa akhir & 5 & $8 \%$ \\
4 & $46-55$ & Lansia awal & 17 & $28 \%$ \\
5 & $56-65$ & Lansia akhir & 39 & $64 \%$ \\
\hline \multicolumn{7}{c}{ Total } & & $\mathbf{6 1}$ & $\mathbf{1 0 0 \%}$ \\
\hline
\end{tabular}

Diabetes melitus sering disertai dengan berbagai penyakit komplikasi. Komplikasi terjadi jika diabetes melitus tidak terkontrol dengan baik serta kebiasaan gaya hidup yang tidak sehat. Rincian karakteristik Pasien Diabetes melitus tipe 2 berdasarkan penyakit. Pada penelitian ini diperoleh pasien DM tipe 2 dengan penyakit komplikasi sebanyak 34 kasus dengan presentase $56 \%$ dan DM tipe 2 tanpa penyakit komplikasi sebanyak 27 kasus dengan persentase $44 \%$. Hal ini menunjukkan bahwa pasien DM tipe 2 di Puskesmas Gedong air banyak yang mengalami penyakit komplikasi, hipertensi menjadi komplikasi terbesar. Komplikasi diabetes melitus disebabkan oleh peningkatan dan penurunan kadar gula darah yang drastis sehingga menyebabkan kerusakan organ tubuh lainya. Menurut Wahyu Putri L, 2013, menyatakan bahwa pasien DM tipe 2 paling banyak mengalami komplikasi sebesar $72 \%$ dan diantaranya penyakit komplikasi terbanyak yaitu hipertensi (16). Rincian berdasarkan Komplikasi Atau Tanpa Komplikasi dapat dilihat pada tabel 3. 
Tabel 3. Karakteristik Pasien Diabetes Melitus Tipe 2 Berdasarkan Penyakit Komplikasi Atau Tanpa Komplikasi

\begin{tabular}{cccc}
\hline No & Kejadian DRPs & Jumlah & Persentase \\
\hline 1 & Komplikasi & 34 & $56 \%$ \\
2 & Tidak Komplikasi & 27 & $44 \%$ \\
\hline Total & & $\mathbf{6 1}$ & $\mathbf{1 0 0 \%}$ \\
\hline
\end{tabular}

Hasil penelitian ini mendapatkan terapi obat antidiabetes diresepkan dalam pengobatan tunggal ataupun kombinasi. penggunaan obat antidiabetik pada pasien DM tipe 2 yang digunakan yaitu obat tunggal dan kombinasi. Pada penelitian ini, dari 61 kasus DM tipe 2 terdapat 31 kasus menggunakan obat tunggal antidiabetik golongan biguanida (metformin), dan 30 kasus menggunakan obat kombinasi (Metformin $+\quad$ glibenklamid). Pengobatan lini pertama DM tipe 2 adalah obat tunggal atau monoterapi manajemen gaya hidup, jika dengan obat tunggal kadar gula darah yang

Tabel 4. Karakteristik Peresepan Obat Antidiabetes

\begin{tabular}{cccc}
\hline Karakteristik Peresepan & Nama Obat Antidiabetes & Jmh & $\%$ \\
\hline Satu macam obat antidiabetes & Metformin & 31 & $51 \%$ \\
Dua macam obat antidiabetes & Metformin + Glibenklamid & 30 & $49 \%$ \\
\hline Total & & 61 & $\mathbf{1 0 0 \%}$ \\
\hline
\end{tabular}

Kejadian Drug Related Problems (DRPs)

Obat tanpa indikasi (unnecessary drug therapy) sebanyak 5 kasus $(7 \%)$, indikasi tanpa obat (Need for additional drug therapy) sebanyak 9 kasus (15\%), obat yang tidak efektif (ineffective drug) diinginkan tidak tercapai maka perlu ada kombinasi obat dari mekanisme yang berbeda untuk meningkatkan efek hipoglikemia (5). Kombinasi Metformin + glibenklamid penggunaanya bekerja saling sinergis yaitu metformin (biguanida) menurunkan produksi glukosa hati dan meningkatkan glukosa dijaringan perifer serta dapat menurunkan berat badan. Sedangkan glibenklamid (sulfonilurea) dapat meningkatkan sekresi insulin (16). Rincian berdasarkan peresepan obat antidiabetes dapat dilihat pada tabel 4 .

tidak ada kejadian (0\%), dosis terlalu rendah (dosage to low) tidak ada kejadian $(0 \%)$, efek samping obat (adverse drug reaction) sebanyak 1 kasus $(2 \%)$, dosis terlalu tinggi (dosage too high) tidak ada kejadian dan interaksi obat potensial sebanyak 29 kasus (48\%).

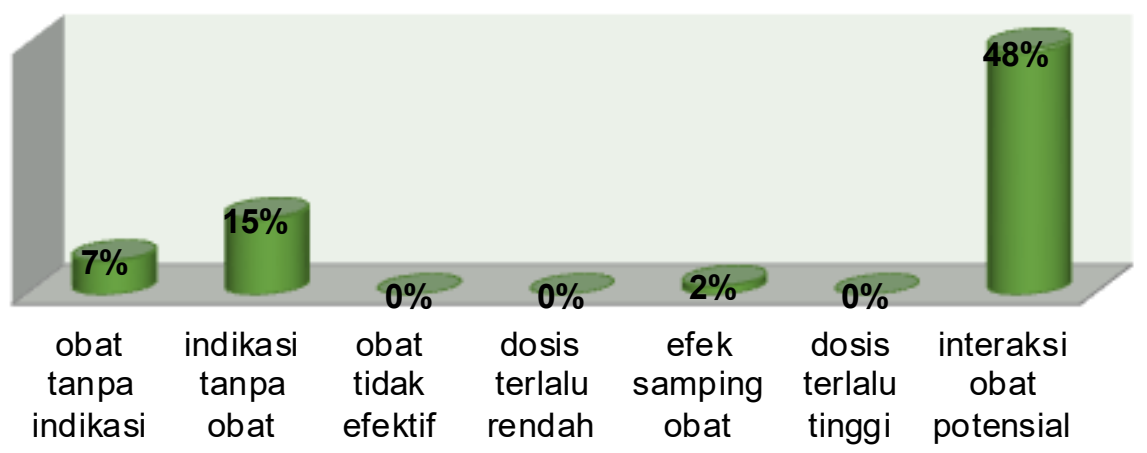

Gambar 1. Persentase DRPs 


\section{Obat Tanpa Indikasi}

DRP obat tanpa indikasi adalah terapi yang tidak diperlukan namun tetap diberikan tanpa indikasi medis yang jelas. Hasil penelitian menunjukan bahwa DRP terapi obat tanpa indikasi menghasilkan kasus sebanyak 4 kasus (7\%) dengan kategori penyebab DRP tidak ada kondisi medis yang sesuai untuk terapi obat pada saat ini. Penyebab DRP kategori tidak ada kondisi medis yang sesuai untuk terapi obat pada saat itu terdapat 3 kasus. Pada kasus tersebut pasien mendapatkan terapi Paracetamol 500 mg 3x1. Paracetamol adalah golongan analgetik antipiretik indikasinya yaitu meredakan nyeri ringan sampai sedang dan demam. Pada, batuk dan DM, tidak ada gejala demam atau nyeri sehingga pemberian paracetamol termasuk obat tanpa indikasi. Sementara terdapat 1 kasus mendapatkan terapi Gliseril Guaiqolat 3x1. Gliserill Guaiqolat adalah golongan ekspektoran, pada DM tidak ada gejala batuk sehingga pemberian Gliserill Guaiqolat termasuk obat tanpa indikasi. Rincian kejadian obat tanpa indikasi dapat dilihat pada Tabel 5.

Tabel 5. Analisis DRP Obat Tanpa Indikasi

\begin{tabular}{|c|c|c|c|}
\hline Penyebab DRPs & Nama Obat & Keterangan & $\begin{array}{l}\text { Nomor } \\
\text { Kasus }\end{array}$ \\
\hline \multirow{2}{*}{$\begin{array}{l}\text { Tidak ada kondisi } \\
\text { medis yang sesuai } \\
\text { untuk terapi obat } \\
\text { pada saat ini }\end{array}$} & $\begin{array}{l}\text { Paracetamol } 500 \\
\text { mg 3x1 }\end{array}$ & $\begin{array}{l}\text { Tidak ada keterangan } \\
\text { keluhan nyeri atau demam } \\
\text { pada rekam medik Pasien }\end{array}$ & 3 \\
\hline & $\begin{array}{l}\text { Gliserill Guaiqolat } \\
3 \times 1\end{array}$ & $\begin{array}{l}\text { Tidak ada keterangan } \\
\text { keluhan batuk pada rekam } \\
\text { medik Pasien }\end{array}$ & 1 \\
\hline
\end{tabular}

\section{Indikasi Tanpa Obat}

Hasil penelitian kejadian DRP terapi indikasi tanpa obat sebanyak 9 kasus $(15 \%)$, dengan rincian kategori kondisi medis membutuhkan sebuah inisiasi terapi obat untuk saat itu sebanyak 3 kasus dan kategori membutuhkan tambahan terapi untuk mencapai efek sinergis dan aditif sebanyak 6 kasus. Terapi indikasi tanpa obat kategori kondisi medis membutuhkan sebuah inisiasi terapi obat terdapat 3 kasus. Pada 2 kasus pasien sama-sama didiagnosa dokter batuk tetapi terapi yang diberikan tidak terdapat obat dengan indikasi tersebut. Seharusnya diberikan obat batuk golongan ekspektoran supaya pasien mendapatkan terapi yang diinginkan tercapai. Pada 1 kasus pasien mengalami keluhan gatal-gatal tetapi tidak diberikan obat dengan indikasi tersebut. Seharusnya diberikan obat golongan antihistamin seperti cetirizine supaya tercapainya terapi yang diinginkan (17). Terapi penyebab DRP membutuhkan tambahan terapi untuk mencapai efek sinergis dan aditif terjadi sebanyak 6 kasus. Pada 3 kasus pasien dengan GDS 220-230 mg/dl pasien hanya mendapatkan monoterapi. Berdasarkan algoritma ADA jika $\mathrm{HbA} 1 \mathrm{c}$ lebih dari $9 \%$ harus menggunakan dua terapi dan menejemen gaya hidup agar kadar glukosa dalam darah itu dapat terkonrol dengan baik, seperti obat golongan sulfonilurea dan glinida. Terdapat 3 kasus pasien dengan GDS 240-261 $\mathrm{mg} / \mathrm{dl}$ pasien hanya mendapatkan monoterapi. Berdasarkan algoritma ADA jika $\mathrm{HbA} 1 \mathrm{c}$ lebih dari $10 \%$ harus menggunakan terapi tiga yaitu 
menejemen gaya hidup, metformin dan dua agen tambahan obat golongan lainya seperti sulfonilurea dan glinida (18). Rincian kejadian indikasi tanpa obat dapat dilihat pada Tabel 6 .

Tabel 6. Analisis DRP Indikasi Tanpa Obat

\begin{tabular}{|c|c|c|c|c|}
\hline $\begin{array}{c}\text { Penyebab } \\
\text { DRP }\end{array}$ & Indikasi & Nama Obat & Rekomendasi & $\begin{array}{l}\text { Jumlah } \\
\text { kasus }\end{array}$ \\
\hline $\begin{array}{l}\text { kondisi } \\
\text { medis } \\
\text { membutuhk } \\
\text { an sebuah } \\
\text { inisiasi } \\
\text { terapi obat } \\
\text { untuk saat } \\
\text { itu }\end{array}$ & $\begin{array}{l}\text { Gatal- } \\
\text { gatal }\end{array}$ & 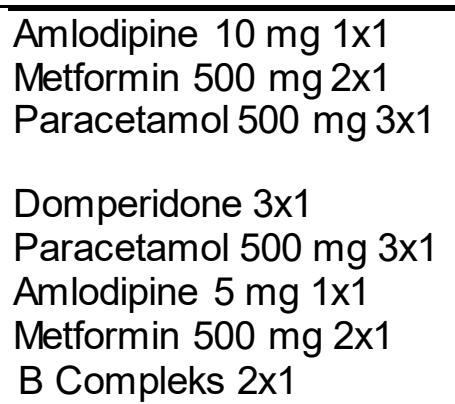 & $\begin{array}{l}\text { Dibutuhkan penambahan } \\
\text { obat batuk seperti } \\
\text { golongan ekpektoran } \\
\text { (17) } \\
\text { Dibutuhkan penambahan } \\
\text { obat gatal-gatal } \\
\text { golongan antihistamin } \\
\text { seperti cetirizine (17) }\end{array}$ & 1 \\
\hline $\begin{array}{l}\text { membutuhk } \\
\text { an } \\
\text { tambahan } \\
\text { terapi untuk } \\
\text { mencapai } \\
\text { efek } \\
\text { sinergis } \\
\text { dan aditif }\end{array}$ & DM tipe 2 & $\begin{array}{l}\text { Metformin } 500 \text { mg 2x1 } \\
\text { Amlodipine } 5 \text { mg 1x1 } \\
\text { B Compleks } 2 \times 1\end{array}$ & 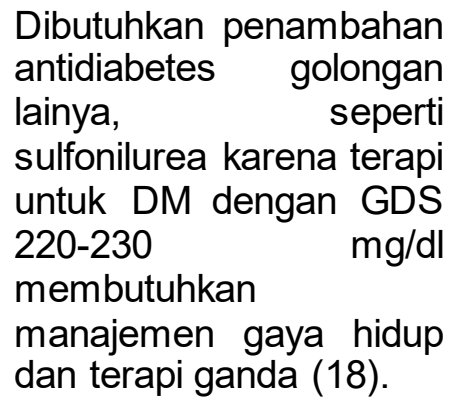 & 3 \\
\hline $\begin{array}{l}\text { membutuhk } \\
\text { an } \\
\text { tambahan } \\
\text { terapi untuk } \\
\text { mencapai } \\
\text { efek } \\
\text { sinergis } \\
\text { dan aditif }\end{array}$ & DM tipe 2 & $\begin{array}{l}\text { Metformin } 500 \text { mg 2x1 } \\
\text { Natrium Diclofenak 2x1 } \\
\text { Gliseril Guaiqolat 3x1 } \\
\text { Vit B 1 2x1 }\end{array}$ & $\begin{array}{l}\text { Dibutuhkan penambahan } \\
\text { antidiabetes golongan } \\
\text { lainya, seperti } \\
\text { sulfonilurea karena terapi } \\
\text { untuk DM dengan GDS } \\
240-261 \quad \mathrm{mg} / \mathrm{dl} \\
\text { membutuhkan } \\
\text { manajemen gaya hidup } \\
\text { dan terapi tiga macam } \\
\text { (18). }\end{array}$ & 3 \\
\hline Total & & & & $15 \%$ \\
\hline
\end{tabular}

\section{Efek Samping Obat}

Hasil penelitian kejadian DRP efek samping obat sebanyak 1 kasus (2\%), dengan rincian kategori Obat merupakan kontraindikasi dengan faktor risiko. Efek samping obat dengan kategori obat merupakan kontraindikasi dengan faktor risiko terdapat 1 kasus. Pada 1 kasus pasien DM dengan penyakit penyerta batuk dan radang, mendapatkan terapi obat metformin $500 \mathrm{mg} 2 \times 1$, ambroxol 3x1, dan dexsametason $3 \times 1$. Pemberian obat dexsametason pada penderita DM dapat meningkatkan produksi glukosa, penurunan indeks sensitivitas insulin serta penurunan bobot badan. Namun tidak terdapat tanda tanda polidipsia dan poliuria (19). Menurut ADA 2018, seseorang yang mengalami diabetes akibat penggunaan dosis besar steroid akan kembali normal kadar gula darahnya ketika penggunaan dihentikan, tetapi akan kembali muncul diabetes beberapa tahun berikutnya 
(18). Rincian kejadian efek samping obat dapat dilihat pada Tabel 7 .

Tabel 7. Analisis DRP Efek Samping Obat

\begin{tabular}{|c|c|c|c|c|}
\hline Penyebab DRPs & Nama obat & \multicolumn{2}{|c|}{ Keterangan } & Jumlah \\
\hline $\begin{array}{l}\text { Obat merupakan } \\
\text { kontraindikasi } \\
\text { dengan faktor risiko }\end{array}$ & Dexsamethason & $\begin{array}{l}\text { Meningkatkan } \\
\text { glukosa }\end{array}$ & produksi & 1 \\
\hline Total & & & & 1 \\
\hline
\end{tabular}

\section{Potensi Interaksi Obat}

Potensi interaksi obat ini di cek menggunakan Tools Medscape Potensi interaksi obat adalah potensi aksi suatu obat diubah atau dipengaruhi oleh obat lain yang diberikan bersamaan. Interaksi obat dapat menyebabkan advers drug reactions apabila potensi terjadi interaksi tersebut tidak diketahui sebelumnya sehingga tidak dapat dilakukan upaya-upaya optimalisasi (20). Keparahan interaksi obat dapat diklasifikasikan ke dalam tiga level yaitu: serious, closely/signifikan dan minor. Mayor/serious mempunyai efek yang dapat berpotensi mengancam nyawa atau menyebabkan kerusakan secara permanen. Moderate/signifikan dapat menyebabkan terjadi penurunan status klinis pasien. Sedangkan tingkat keparahan minor efek yang ditimbulkan tidak mengganggu atau tidak terlihat secara signifikan sehingga tidak diperlukan terapi tambahan (21).

Hasil penelitiaan ini ditemukan 29 kasus potensi interaksi obat.Kombinasi Metformin-Dexsamethason,

berdasarkan hasil analisis, terdapat 1 pasien yang mengalami interaksi metformin-dexsamethason.

Dexsamethason dapat mengganggu efektivitas metformin oleh antagonisme farmakodinamika, interaksi ini masuk kedalam kejadian interaksi minor (21).

Amlodipine - Metformin, berdasarkan hasil analisis, terdapat 27 pasien yang mengalami interaksi amlodipinemetformin. Kombinasi amlodipine dengan metformin dapat menurunkan efek metformin oleh farmakodinamika antagonisnya, interaksi ini masuk kedalam kejadian interaksi moderate/signifikan (21).

Amlodipine-Simvastatin, berdasarkan hasil analisis, terdapat 1 pasien yang mengalami interaksi amlodipinesimvastatin. Amlodipin dapat meningkatkan level simvastatin. Kombinasi kedua obat ini harus diberikan dengan hati-hati karena dapat meningkatkan resiko potensi dari myopaty/rehabdomyolisis Myopaty adalah semua kelainan dimana terdapat gangguan primer pada fungsi dan struktur otak (22). Perlu dilakukan pembatasan dosis simvastatin tidak boleh lebih dari 20 $\mathrm{mg}$ /hari. Interaksi ini masuk kedalam kejadian interaksi Mayor/serious (21).

Hasil beberapa studi terdahulu melaporkan bahwa identifikasi potensi interaksi obat pada pasien DM merupakan kategori DRPs tertinggi dan persentasenya bervariasi. Studi Khoirotun Nazilah et al, 2017 dalam studinya melaporkan bahwa pasien terdapat $66,67 \%$ pasien mengalami potensi interaksi obat (23). Verona Shaqila Efimaralda, 2016, dalam studinya melaporkan bahwa pasien terdapat57,78\% pasien mengalami potensi interaksi obat (24). Dhenny Arman Siregar, 2018, dalam studinya melaporkan bahwa pasien terdapat $70,90 \%$ pasien mengalami kategori potensi interaksi obat (25). Interaksi obat potensial dapat dilihat pada Tabel 8. 
Tabel 8. Potensi Interaksi Obat

\begin{tabular}{|c|c|}
\hline $\begin{array}{l}\text { Tnteraksi } \\
\text { obat }\end{array}$ & $\begin{array}{c}\text { Level } \\
\text { signifika } \\
n\end{array}$ \\
\hline 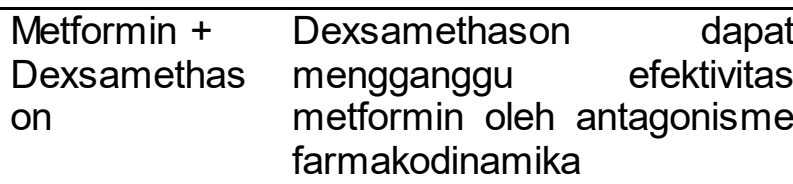 & $\begin{array}{l}\text { Dexsamethason } \\
\text { mengurangi efek } \\
\text { metformin }\end{array}$ \\
\hline 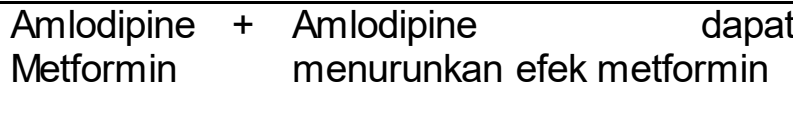 & $\begin{array}{l}\text { Amlodipine } \\
\text { mengurangi efek } \\
\text { metformin }\end{array}$ \\
\hline \multirow[t]{2}{*}{$\begin{array}{lll}\text { Amlodipine } & + & \text { Amlodipine } \\
\text { Simvastatin } & \text { kadar simvastatin }\end{array}$} & $\begin{array}{cl}\begin{array}{c}\text { Mayor/se } \\
\text { rious }\end{array} & \text { Amlodipine } \\
& \text { meningkatkan } \\
& \text { efek simvastatin }\end{array}$ \\
\hline & tal \\
\hline Jumlah Kejadian DRPs & $\begin{array}{l}\text { DRPs sebanyak } \\
\text { mengalami DRPs }(26) .\end{array}$ \\
\hline $\begin{array}{l}\text { Berdasarkan hasil analisis sebanyak } 28 \\
\text { pasien } 46 \% \text { teridentifikasi mengalami } \\
\text { kejadian DRPs dan sebanyak } 33 \\
\text { pasien } 54 \% \text { yang tidak mengalami } \\
\text { kejadian DRPs. Menurut Nazilah et al, } \\
2017 \text {, dalam studinya melaporkan } \\
\text { bahwa pasien terdapat } 15 \% \text { pasien DM } \\
\text { mengalami DRPs (23). Hasil serupa } \\
\text { juga dilaporkan Pamungkas, } 2017 \\
\text { menyatakan bahwa terdapat kejadian }\end{array}$ & $\begin{array}{l}\text { Dampak DRPs pada diabetes melitus } \\
\text { yaitu terjadi ketidak sesuaian dalam } \\
\text { pencapaian tujuan terapi menyebabkan } \\
\text { pemberian yang tidak tepat bisa } \\
\text { mengakibatkan gulkosa dalam darah } \\
\text { tidak setabil, terjadi juga interaksi obat } \\
\text { satu dengan yang lain mengakibatkan } \\
\text { obat tidak bekerja secara efektif lagi } \\
\text { (8). Rincian kejadian DRPs pada hasil } \\
\text { identifikasi penelitian ini dapat dilihat } \\
\text { pada Gambar } 2 \text {. }\end{array}$ \\
\hline
\end{tabular}

\section{Persentase Kejadian DRPs}

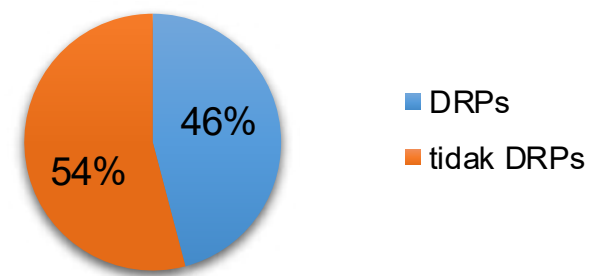

Gambar 2. Jumlah Kejadian DRPs

\section{Kesimpulan}

Berdasarkan penelitian yang dilakukan maka dapat disimpulkan bahwa ada kejadian DRPs pada 61 pasien dengan diagnosis DM tipe 2 di UPT Puskesmas Rawat Inap Gedong Air periode Agustus 2018 - Agustus 2019.

1. Terdapat 28 pasien (46\%) teridentifikasi mengalami DRPs dan 33 kasus (54\%) tidak terdapat DRPs dari total 61 sampel rekam medik pasien DM tipe 2 terdapat di UPT Puskesmas Rawat Inap Gedong Air periode Agustus 2018 Agustus 2019.

2. Jumlah kejadian dan rincian kategori DRPs Diabetes Melitus tipe 2 di UPT Puskesmas Rawat Inap Gedong Air periode Agustus 2018 - Agustus 2019:Obat tanpa indikasi (unnecessary drug therapy) sebanyak 4 kasus $(7 \%)$, indikasi tanpa obat (Need for 
additional drug therapy) sebanyak 9 kasus (15\%), obat yang tidak efektif (ineffective drug) tidak ada kejadian $(0 \%)$, dosis terlalu rendah (dosage to low) tidak ada kejadian $(0 \%)$, efek samping obat (adverse drug reaction) sebanyak 1 kasus $(2 \%)$, dosis terlalu tinggi (dosage too high) tidak ada kejadian dan potensi interaksi obat sebanyak 29 kasus $(48 \%)$.

\section{DAFTAR PUSTAKA}

1. Kementrian Kesehatan Republik Indonesia. 2018. Hari Diabetes Sedunia Tahun 2018. Jakarta Selatan: Pusat Data Dan Informasi Kementrian Kesehatan RI. 24427659 .

2. Kementrian Kesehatan Badan Penelitian Dan Pengembangan Kesehatan. 2018. Hasil Utama Riskesdas 2018. Jakarta: Kementrian Kesehatan Republik Indonesia. P. 57.

3. Dinas Kesehatan Pemerintah Provinsi Lampung.2015. Profil Provinsi Lampung. Teluk Betung Bandar Lampung: Dinas Kesehatan Pemerintah Provinsi Lampung. P. 45.

4. Kementrian Kesehatan Republik Indonesia. Klasifikasi Diabetes Melitus 2009: Diambil DariWww.Depkes.Go.Id. Diakses 8 Juli 2019 Pukul 11.45 WIB.

5. A. D. Rudijanto. 2015. Konsensus Pengelolaan Dan Pencegahan Diabetes Melitus Tipe 2 Di Indonesia 2015. Edisi V. Jakarta: Pengurus Besar Perkumpulan Endokrinologi Indonesia (PB PERKENI). 978-979

6. Menteri Kehatan Republik Indonesia. 2015. Peraturan Menteri Kesehatan Republik Indonesia Nomor 67 Tahun 2015 Tentang Penyelenggaraan Pelayanan Kesehatan Lanjut Usia Di Pusat Kesehatan Masyarakat. Peraturan Menteri Kesehatan Republik Indonesia. Jakarta.
7. G. M. Al-Taani Et Al.2017. Prediction Of Drug-Related Problems In Diabetic Outpatients In A Number Of Hospitals, Using A Modeling Approach. Dove Press Journal Drug, HealthcPatient Saf. Irbid Jordan. 965-70.

8. M. Robert J Cipolle, Linda M. Stand. 2004 "Pharmaceutical Care Practice 2nd Edition,"Mcgraw-Hill. New York. 007-1362.

9. Y. Ayele, K. Melaku, M. DechasaEt Al. 2018. Assessment Of Drug Related Problems Among Type 2 Diabetes Mellitus Patients With Hypertension In Hiwot Fana Specialized University Hospital, Harar, Eastern Ethiopia. BMC ResNotes.Harar Ethiopia. 11:728.

10. Nur Wijayanti. 2016. Identifikasi Drug Related Problems (Drps) Potensial Pada Pasien Diabetes MelitusTipe 2 Di Instalasi Rawat Inap RS X Tahun 2015. Universitas Muhamadiyah. Surakarta.

11. D. S. W. Claudia Pingkan Lira, Widya Astuty Lolo. 2017. Potensi Drug Related Problems(Drps) Penggunaan Obat Antidiabetes Pada Pasien Diabetes Melitus Tipe 2 Di Instalasi Rawat Inap Rumah Sakit Kalooran Gmim Amurang. FMIPA UNSRAT. Manado. Vol. 6 No 4 November: 2303-2493.

12. Lee Chai Ling Hasniza Zaman Huri. 2013. Drug Related Problems Type 2 Diabetes Mellitus Patien With Dyslipidemia. University Of Malaya. BMC Public Health. Malaysia. 13:1192.

13. Departement Kesehatan Republik Indonesia. 2006. Pedoman Pelayanan Kefarmasian Di Puskesmas. Jakarta.

14. Enggar Fitria Nur Susanti. 2019 "gambaran faktor resiko terjadinya DM pada penderita DM tipe 2". Universitas Muhamadiyah Surakarta. Surakarta.

15. Arnold Hongdiyanto, 2014 "Paulina dan $H$. Evaluasi Kerasionalan Pengobatan Diabetes Melitus Tipe 2 pada Pasien Rawat Inap Di 
RSUP Prof .Dr.R.D Kandau Manado". Manado, Jurnal IImiah Farmasi.

16. Wahyu Putri Lestari. 2013 "gambaran efektifitas penggunaan obat antidiabetik tunggal dan kombinasi dalam mengendalikan gula darah pada pasien DM tipe 2 di Rumah sakit Umum Pusat Fatmawati Tnun 2012". jakarta, fakultas Kedokteran Dan IImu Kesehatan Jakarta.

17. MMN. 2017. Basic Pharmacology And Drug Notes. MMN Publishing.Makasar.

18. Freinkel Norbert. 2018. American Diabetes AssosiationStandards Of Medical Care In Diabetes 2018, The Journal Of Clinical And Applied Research And Education. Amerika. Vol. 41, No 1. 014-5992

19. Rahmania Hanim. 2017 "karakteristik tipe diabetes pada kandidat tikus model yang diinduksi deksametason". Bogor, Bogor Agricultural.

20. Andriana Sari, D. W. B. R, "2012 Identifikasi Potensi Interaksi Obat Pada Pasien Rawat Inap Penyakit Dalam Di RSUD Prof. Dr. Margono Soekarjo Purwokerto Dengan Metode Observasional Retrospektif Periode November 2009-Januari 2010".
21. Tools Medscape, 2020"Medscape".

22. Kurniawan S, D. R. 2017"Buku Ajar Miopati”Fakultas Kedokteran Universitas BrawijayaUB Press.

23. K. Nazilah, E. Rachmawati, And P. B. Subagijo. 2017. Identifikasi Drug Related Problems (Drps) Pada Terapi Diabetes Melitus Tipe 2 Di Instalasi Rawat Inap RSD Dr.Soebandi Jember Periode Tahun 2015. UNEJ. Jember. Vol 5 (3) September 2017.

24. Verona Shaqila Efmaralda, 2016“Pengaruh Drug Related Problems Terhadap Outcomes Klinik Pasien Diabetes Melitus Di Instalasi Rawat Inap RS X Di Tanggerng Selatan Periode Juli 2014- Juni 2015,".

25. Dhenny Arman Siregar. 2018 "Identifikasi Drug Related Problems (DRPs) Pada Pasien Diabetes Melitus Tipe 2 Dengan Penyakit Penyerta Hipertensi Dilantai 5 Teratai Rumah Sakit Umum Pusat (RSUP) Fatmawati Periode Bulan Januari - Juni 2016".

26. Mayang Biyan Pamungas, 2017 "Analisis Darug Related Problems Pada Pasien Diabetes Melitus Tipe 2 Dengan Hipertensi Di Rumah Sakit Umum Daerah Dr.Soehadi Prijonegoro Sragen Periode 2016,". 